Discussion Paper No. 13-044

\title{
Profit Shifting and 'Aggressive' Tax Planning by Multinational Firms: Issues and Options for Reform
}

Clemens Fuest, Christoph Spengel, Katharina Finke, Jost Heckemeyer, and Hannah Nusser

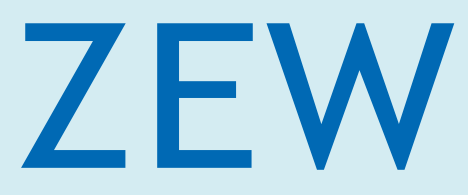

Zentrum für Europäische Wirtschaftsforschung $\mathrm{GmbH}$ Centre for European Economic Research 
Discussion Paper No. 13-044

\title{
Profit Shifting and 'Aggressive' Tax Planning by Multinational Firms: Issues and Options for Reform
}

\author{
Clemens Fuest, Christoph Spengel, \\ Katharina Finke, Jost Heckemeyer, \\ and Hannah Nusser
}

Download this ZEW Discussion Paper from our ftp server:

http://ftp.zew.de/pub/zew-docs/dp/dp13044.pdf

Die Discussion Papers dienen einer möglichst schnellen Verbreitung von neueren Forschungsarbeiten des ZEW. Die Beiträge liegen in alleiniger Verantwortung der Autoren und stellen nicht notwendigerweise die Meinung des ZEW dar.

Discussion Papers are intended to make results of ZEW research promptly available to other economists in order to encourage discussion and suggestions for revisions. The authors are solely responsible for the contents which do not necessarily represent the opinion of the ZEW. 


\section{Non-technical Summary}

Google, Apple and other highly profitable multinationals are able to drastically reduce their tax burden on worldwide income by shifting profits from high- to low-tax countries. Reports on these tax avoidance strategies have triggered an intense public debate, which has brought the issue to the top of the international policy agenda. Both the OECD and the EU Commission are currently working on measures to fight tax avoidance and profit shifting by multinational firms and have already published first recommendations.

This paper contributes to the current debate in two ways: First, we provide background information for a better understanding of the issue. Second, we discuss different policy options to address tax avoidance and profit shifting by multinationals and derive recommendations for policy makers. As most companies currently accused of avoiding taxes use intra-group licensing to shift profits, we focus on IP-based profit shifting but do also elaborate on profit shifting in general.

Based on a detailed description of typical tax planning strategies of multinational firms, we reveal central flaws and loopholes in tax law. Moreover, we show that there is solid empirical evidence demonstrating that profit shifting is indeed taking place but little is known about the tax revenue consequences of profit shifting.

With respect to the policy options, we differentiate between four general approaches for tackling profit shifting and tax avoidance by multinational firms:

(1) Extension of residence taxation

(2) Extension of source taxation

(3) Fundamental reforms of corporate income taxation

(4) Stricter reporting and transparency requirements

We argue that strengthening residence taxation, for example by tightening CFC rules, is an effective reform option but has the disadvantage that some countries benefit from a weak residence taxation and, hence, might be reluctant to move in this direction. Enforcing source taxation, on the other hand, is more promising. In the short run, we especially recommend extending withholding taxes in an internationally coordinated way. This measure effectively tackles profit shifting without causing double taxation. Unilateral measures for strengthening source taxation, like for example deduction restriction rules for interest and license payments or a general anti-avoidance measures, are not recommended because the first are economically harmful and the second are presumably ineffective. For the longer perspective, we recommend the more fundamental reform options, like formula apportionment or a destination-based tax, to be further promoted. Stricter reporting and transparency requirements, like country-bycountry reporting, do face serious legal constraints and it is questionable whether the benefit of such rules justifies the corresponding high effort and costs. 


\section{Das Wichtigste in Kürze}

Google, Apple und anderen hochprofitablen multinationalen Konzernen gelingt es, ihre weltweite Steuerbelastung durch die Verlagerung von Gewinnen in Niedrigsteuerländer drastisch zu senken. Berichte über diese Steuervermeidungspraktiken haben eine intensive öffentliche Debatte ausgelöst und die internationale Politik zum Handeln veranlasst. Sowohl die OECD als auch die EU Kommission arbeiten derzeit an Maßnahmen zur Bekämpfung von Steuervermeidung und Gewinnverlagerung durch multinationale Unternehmen und haben bereits erste Empfehlungen veröffentlicht.

Dieses Diskussionspapier leistet in zweierlei Hinsicht einen Beitrag zur aktuellen Debatte: Zum einen geben wir Hintergrundinformationen, die zu einem besseren Verständnis der Problematik beitragen sollen. Zum anderen diskutieren wir verschiedene Maßnahmen zur Bekämpfung internationaler Gewinnverlagerung und geben Handlungsempfehlungen. Da die meisten der derzeit aufgrund ihrer Steuerplanungsstrategien in der Kritik stehenden Unternehmen Gewinne durch gruppeninterne Lizenzierungsgestaltungen verschieben, gehen wir insbesondere auf diese Form der Gewinnverlagerung ein.

Basierend auf einer detaillierten Beschreibung typischer Steuerplanungsstrategien multinationaler Konzerne decken wir die zentralen Schwachstellen und Schlupflöcher im bestehenden Steuersystem auf. Zudem zeigen wir, dass ein Gewinnverlagerungsverhalten multinationaler Unternehmen empirisch erwiesen ist, jedoch nur wenig über die Auswirkungen von Gewinnverlagerung auf das Steueraufkommen bekannt ist.

Bei der Diskussion der Handlungsalternativen unterscheiden wir zwischen vier grundlegenden Ansätzen zur Bekämpfung von Steuervermeidung und Gewinnverlagerung durch multinationale Konzerne:

(1) Ausweitung der Wohnsitzbesteuerung

(2) Ausweitung der Quellenbesteuerung

(3) Fundamentale Reformen der Körperschaftsteuer

(4) Strengere Berichts- und Transparenzanforderungen

Wir argumentieren, dass eine Stärkung der Wohnsitzbesteuerung, zum Beispiel durch eine Verschärfung von Regelungen zur Hinzurechnungsbesteuerung, eine effektive Reformoption darstellt, die jedoch nur schwer durchsetzbar sein dürfte, da einige Länder von einer schwachen Wohnsitzbesteuerung profitieren. Eine Stärkung der Quellenbesteuerung ist vielversprechender. Als kurzfristige Maßnahme empfehlen wir insbesondere eine international koordinierte Ausweitung der Erhebung von Quellensteuern. Diese Maßnahme bekämpft effektiv Gewinnverlagerung ohne eine Doppelbesteuerung auszulösen. Unilaterale Maßnahmen zur Stärkung der Quellenbesteuerung, wie Abzugsbeschränkungen für Zins- und Lizenzzahlungen oder generelle Anti-Missbrauchs Vorschriften, sind hingegen nicht empfehlenswert, da erstere ökonomisch schädlich und letztere nur wenig effektiv sind. Langfristig erachten wir es als sinnvoll, fundamentalere Reformmaßnahmen, wie z.B. eine formelhafte Gewinnaufteilung oder eine am Bestimmungsland anknüpfende Steuer, weiter voranzutreiben. Strengeren Berichts- und Transparenzanforderungen, wie z. B. country-bycountry reporting, stehen rechtliche Beschränkungen entgegen und es ist fraglich, ob der Nutzen solcher Maßnahmen die dadurch entstehenden Kosten und den resultierenden Aufwand rechtfertigt. 


\title{
Profit Shifting and 'Aggressive' Tax Planning by Multinational Firms: Issues and Options for Reform
}

\author{
Clemens Fuest*, Christoph Spengel**, \\ Katharina Finke***, Jost Heckemeyer**, Hannah Nusser****
}

July 2013

\begin{abstract}
This paper discusses the issue of profit shifting and 'aggressive' tax planning by multinational firms. The paper makes two contributions. Firstly, we provide some background information to the debate by giving a brief overview over existing empirical studies on profit shifting and by describing arrangements for IP-based profit shifting which are used by the companies currently accused of avoiding taxes. We then show that preventing this type of tax avoidance is, in principle, straightforward. Secondly, we argue that, in the short term, policy makers should focus on extending withholding taxes in an internationally coordinated way. Other measures which are currently being discussed, in particular unilateral measures like limitations on interest and license deduction, fundamental reforms of the international tax system and country-by-country reporting, are either economically harmful or need to be elaborated much further before their introduction can be considered.
\end{abstract}

JEL Classification: H20, H25, F23, K34

Keywords: tax avoidance; profit shifting; multinational firms; intellectual property; tax policy; tax reform

\footnotetext{
* ZEW Mannheim \& University of Mannheim

** University of Mannheim \& ZEW Mannheim

*** ZEW Mannheim

**** University of Mannheim
} 


\section{Motivation}

Recent media reports have drawn attention to the fact that some highly profitable multinational companies seem to pay almost no corporate income tax. The effective tax rates on foreign profits of Google and Apple, for example, have been reported to be less than $3 \%$ and $1 \%$, respectively. ${ }^{1}$ This has triggered an intense public debate about profit shifting and tax avoidance by multinational firms. Given that many countries face high levels of debt and huge pressure to generate tax revenue, it is not surprising that this debate has brought the taxation of multinational firms to the top of the international policy agenda.

The G-20 leaders first stressed the need to take action against multinational profit shifting and tax avoidance at the Summit in Los Cabos in June 2012. On 12 February 2013 the OECD published its report 'Addressing Base Erosion and Profit Shifting', which summarizes the interim findings of the OECD's ongoing work in this field and identifies key pressure areas. A subsequent global action plan of the OECD with 15 comprehensive actions was released on 19 July 2013. ${ }^{3}$ The deadlines for elaborating concrete recommendations on how to address these actions reach until September 2014 and December 2015 respectively. The European Commission has also started to address the issue. On 6 December 2012 the Commission adopted an action plan ${ }^{4}$ and two recommendations ${ }^{5}$ to tackle tax fraud, tax evasion and aggressive tax planning. Moreover, at the EU Summit on 22 May 2013, the EU Council agreed to accelerate the work on recommendations against tax fraud, tax evasion and aggressive tax planning and announced to report back on progress on these topics by December $2013 .{ }^{6}$ Finally, there is an ongoing political debate in many countries on how aggressive tax planning might be tackled. ${ }^{7}$

The fact that some multinationals are able to drastically reduce their tax liability by exploiting loopholes in existing tax rules does suggest that the taxation of multinational firms is in need of reform. It is the objective of this paper to (1) explain how profit shifting in multinational companies works and (2) discuss policy options to address this issue. We do so by focusing on profit shifting which involves the use of intellectual property (IP) because this asset class has two important characteristics: Firstly, it is a driver of value creation in multinational firms.

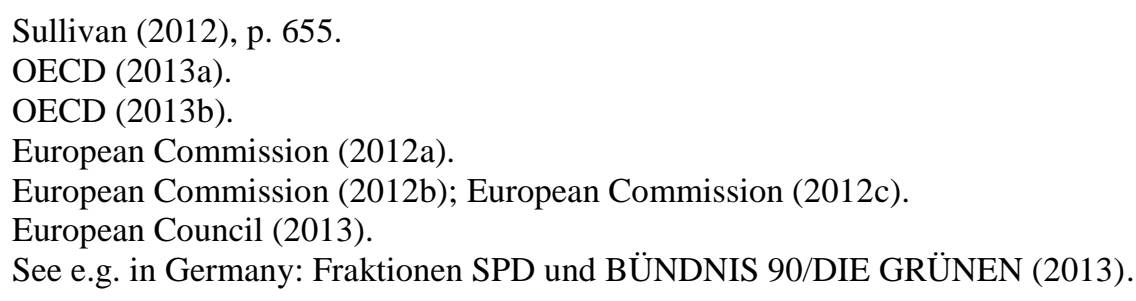


Secondly, IP is highly mobile. These characteristics imply that IP plays an important role in international profit shifting. It is no surprise that most of the companies currently accused of avoiding taxes have IP intensive business models. Of course, this does not mean that other channels like e.g. intra-group debt financing are unimportant. Therefore, the policy options discussed in the following address profit shifting in general and specific IP-tax planning strategies in particular.

There are many ways in which policy makers can try to combat tax avoidance and profit shifting. For the following discussion it is helpful to distinguish four approaches:

(1) Extension of residence based taxation for example by tightening CFC rules.

(2) Extension of source based taxation. This can be achieved, firstly, through unilateral measures or, secondly, through measures requiring international coordination. The first approach includes, for instance, targeted measures like thin-capitalization rules. An example for the second approach is the extension of withholding taxes on border crossing interest or royalty payments. This will typically involve changes of existing double taxation agreements and EU Directives, so that multilateral coordination is required here.

(3) Fundamental reform of corporate income taxation. This includes reform concepts like the introduction of worldwide formula apportionment or destination-based corporate taxation.

(4) A reform of the reporting and transparency rules in international taxation like the obligation for tax advisers to report tax avoidance schemes or country-by-country reporting of multinational investors.

Approach 1 can be effective but has the disadvantage that some countries benefit from certain forms of profit shifting and therefore may not be willing to extend their own residence based taxation. In addition, from the perspective of an individual country extending residence based taxation addresses tax avoidance related to foreign subsidiaries of domestic multinationals but not tax avoidance by domestic subsidiaries of foreign parent companies. With respect to approach 2 unilateral measures have the attractive feature that by definition no international coordination is required. The drawback is that this will almost inevitably lead to double taxation and undermine the consistency of the national as well as the international tax system. If restricted to multilateral measures, approach 2 would be an effective way of pushing back tax avoidance. Of course, here again the challenge is that different countries may have very different interests. As we explain in greater detail below, existing arrangements to avoid 
taxation of income related to IP and related profit shifting activities could be addressed by reforms of source based taxation. This includes, inter alia, tightening transfer prices and exit taxes, extending withholding taxes on royalties and interest payments, or reforming the definition of permanent establishments. Approach 3, a fundamental reform of international corporate taxation, is desirable but clearly a long term project. Approach 4 may help but raises a number of complicated issues.

The rest of the paper is organized as follows: First, we describe arrangements for IP-based profit shifting which are used by the companies currently accused of avoiding taxes in section 2 . We do so to identify the distinct elements of taxation rendering those strategies possible. In Section 3 we elaborate on the actual significance of the problem of profit shifting by providing an overview of empirical studies on the extent and forms of multinational profit shifting. Following this, in section 4 we describe the prevailing concepts of international taxation and their desirable application. In section 5 we discuss different policy options to address profit shifting. Section 6 concludes.

\section{Prominent models for IP-based profit shifting}

The companies that have recently been reported to drastically reduce their tax liability all own firm-specific intellectual property and shift profits via intra-group licensing. Therefore, we focus on IP-based profit shifting strategies here and do not elaborate on strategies using other profit shifting channels. However, the policy options discussed in section 5 also address other tax planning strategies. In the following, we present two representative IP-based tax planning strategies that are commonly used by multinationals and identify the central flaws and loopholes in national and international tax law rendering these tax avoidance strategies possible.

\section{1. 'Double Irish Dutch Sandwich'}

The tax planning technique that Google and many other U.S. IT-firms use to reduce their tax liability on non-U.S. income has become famous as 'Double Irish Dutch Sandwich'. ${ }^{8}$ As its name implies, the structure involves two companies incorporated in Ireland, one IP-Holding and one Operating Company, and one Conduit Company incorporated in the Netherlands. The IP-Holding Company is a direct subsidiary of the U.S. Parent Company and the single owner of the Irish Operating Company and the Dutch Conduit Company. The IP-Holding is managed

\footnotetext{
8 For a detailed description of the structure see also Sandell (2012); Pinkernell (2012).
} 
and controlled in Bermuda and therefore considered resident in Bermuda for Irish tax purposes. The U.S., on the contrary, treats the company as an Irish corporation because tax residency is based on jurisdiction of incorporation according to U.S. tax law.

Figure 1 summarizes the structure. In the following the single steps and elements of the 'Double Irish Dutch Sandwich' are explained in detail.

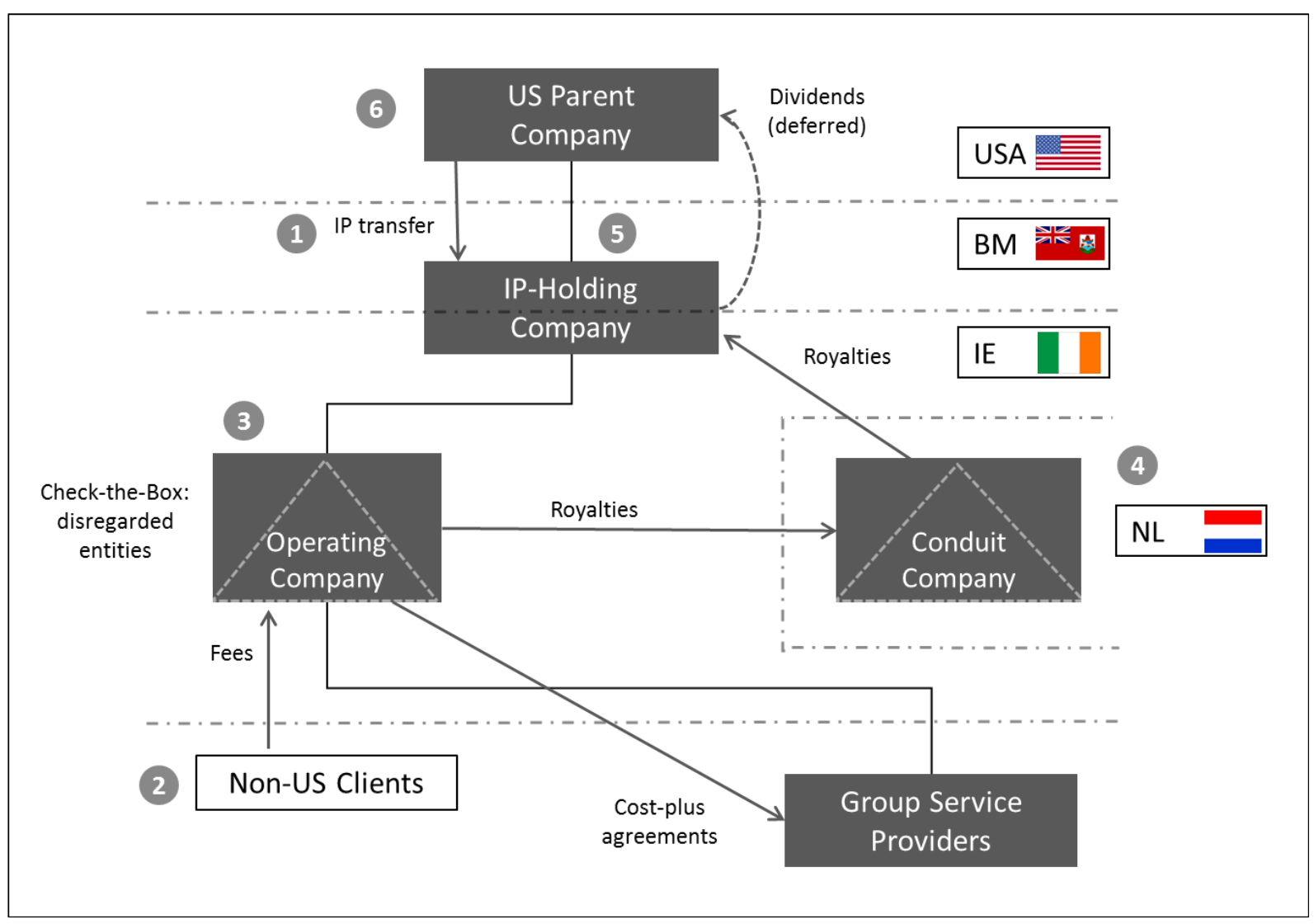

Figure 1: 'Double Irish Dutch Sandwich'

\section{(1) Low tax payment on the initial IP transfer}

To set up the structure, the U.S. parent company first has to transfer the rights to use its IP outside the U.S. to the IP-Holding Company. As transferring the full-fledged intangible would trigger taxation of hidden reserves and future income generated by the intangible according to the U.S. super-royalty-rule, ${ }^{9}$ the IP-Holding Company instead makes a buy-in-payment and concludes a cost-sharing agreement on the future modification and enhancement of the IP with

9 IRC Sec. 482, according to this rule transfer prices determined at the time of transfer that are not commensurate with the income attributable to the intangible may be adjusted later on. 
the U.S. Parent Company. Consequently, the IP-Holding owns the non-U.S. IP rights developed under the cost sharing agreement and therefore no periodic license payments have to be made to the U.S. Parent Company. Determining the arm's length price for the buy-in payment is usually very difficult as the intangible is only partially developed at the time of transfer and risk is associated with future earnings. Hence, multinationals have considerable leeway in determining the price and are able to avoid high exit taxes.

\section{(2) Almost no taxation in the country of final consumption due to e-commerce}

Multinationals using the 'Double Irish Dutch Sandwich' often provide services and sell goods via the internet. The Irish Operating Company thereby acts as the contractual partner of all nonU.S. customers buying these services and products. Hence, no physical presence is created in the country of final consumption and the profits cannot be taxed there. Functions like the delivery of products, manufacturing or marketing activities are usually assigned to low risk group companies located in the customers' residence states. These group service providers work on a cost-plus basis keeping the tax base in the country of final consumption low.

\section{(3) Setting high royalty payments reduces taxation at the level of the Operating Company}

The profits from customer sales earned by the Operating Company are subject to tax in Ireland. However, the tax base of the Operating Company is close to zero because it pays high taxdeductible royalties for the use of the IP held by the IP-Holding Company. As Ireland has only recently introduced transfer pricing rules and these rules do not apply to contracts and terms agreed on before July 2010, most companies using the 'Double Irish Dutch Sandwich' presumably can set the price of the royalty payments as high as they want.

(4) Interposition of Dutch Conduit Company to avoid withholding taxes on profits leaving the $E U$

The royalties are not paid directly to the IP-Holding Company but are passed through a Conduit Company in the Netherlands, which sublicenses the IP. The Dutch Conduit Company does not perform any economic activity. It is interposed because the IP-Holding Company is a Bermuda resident for Irish tax purposes and Ireland levies withholding tax on royalty payments to Bermuda. By channeling the royalties over the Dutch Conduit Company, withholding taxes can be completely circumvented as royalties paid from Ireland to the Netherlands are tax-free under the EU Interest and Royalty Directive and the Netherlands do not impose withholding tax on 
any royalty payments, irrespective of the residence state of the receiving company. The tax liability of the Conduit Company in the Netherlands only consists of a small fee payable for the use of the Dutch tax system.

\section{(5) IP-Holding Company untaxed in Ireland and Bermuda}

The IP-Holding Company is neither subject to tax in Ireland nor in Bermuda since Ireland considers the company a non-resident and Bermuda does not impose tax on corporations. Hence, the profits earned in the EU leave the EU virtually untaxed.

\section{(6) U.S. CFC rules are circumvented due to check-the-box election}

The U.S. also does not tax the non-U.S. income as long as it is not redistributed as dividends or qualified as Subpart F Income. To avoid the latter, the Irish Operating Company and the Dutch Conduit Company file a check-the-box election with the consequence that both Irish subsidiaries and the Dutch Conduit Company are treated as one single Irish corporation and their incomes are combined for U.S. tax purposes. The royalty payments between the companies thus are disregarded and only revenues from transactions with customers, which do not constitute Subpart F income, ${ }^{10}$ are considered from a U.S. perspective.

\subsection{IP-Holding Structure using IP Box Regime}

The 'Double Irish Dutch Sandwich' is only one example for how IP-Holdings can be used to minimize taxes. Another possibility is to transfer the IP to an IP-Holding Company resident in a European country that offers a special IP Box Regime, like for example Luxembourg, Belgium or the UK. The Operating Company can generally be resident in any EU member state. However, locating it in a country that does not strictly apply the arm's length principle allows increasing the amount of profits shifted. As in the case of the 'Double Irish Dutch Sandwich', the structure requires that no CFC rules in the residence country of the parent company apply and that the IP can be transferred without triggering high exit taxes.

10 This is due to the so-called manufacturing exception in IRC Sec. 954(d)(1)(A), see Sandell (2012), p. 874. 


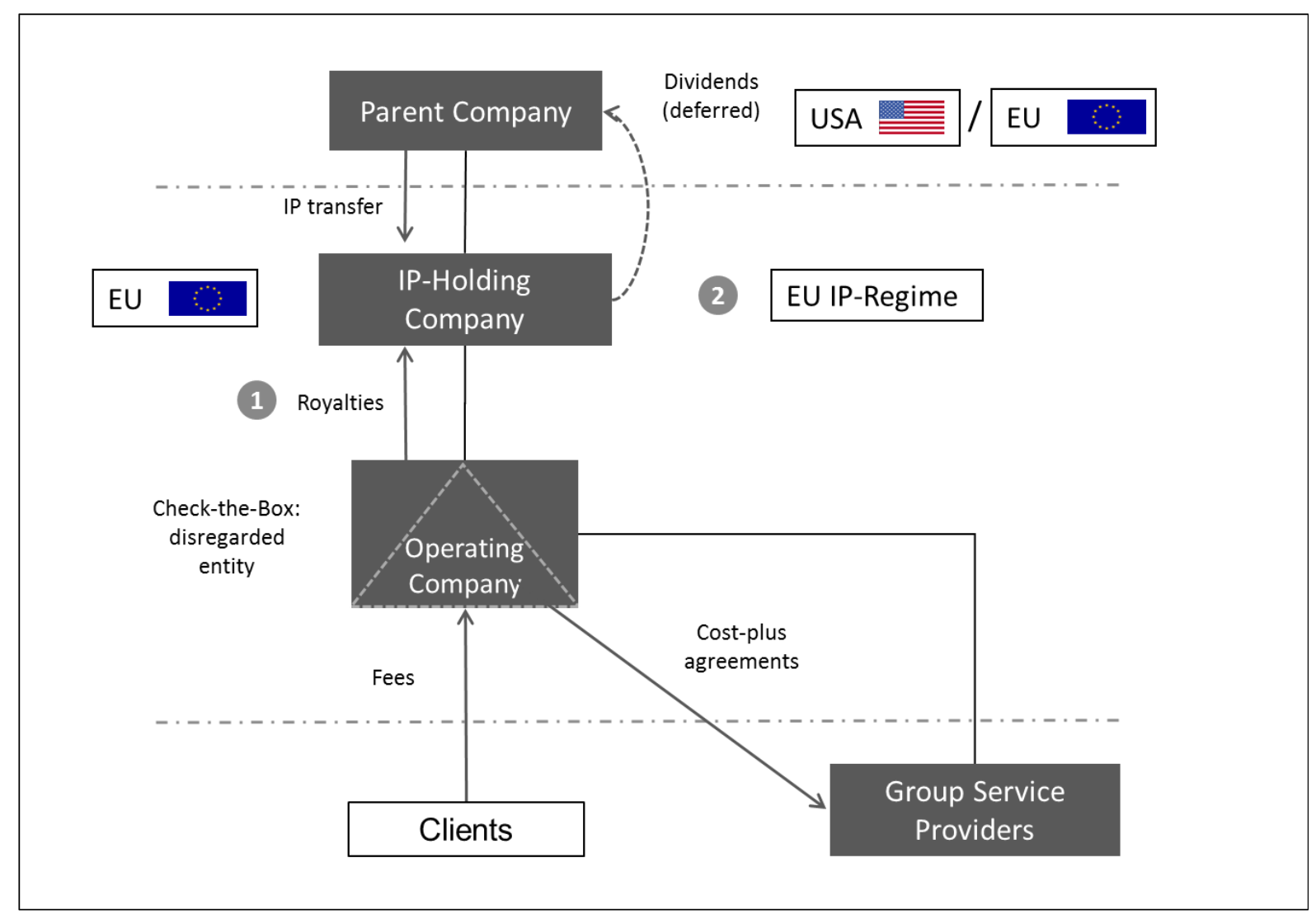

Figure 2: IP-Holding Structure

Figure 2 summarizes the IP-Holding Structure. The two main differences to the 'Double Irish Dutch Sandwich' structure are described in the following.

\section{(1) Avoidance of withholding tax due to Interest and Royalty Directive}

The Operating Company pays royalties directly to the IP-Holding Company. No conduit company needs to be interposed to avoid withholding tax as the IP-Holding Company is located in an EU member state and therefore the Interest and Royalty Directive applies.

\section{(2) Low taxation of the royalties at the level of the IP-Holding Company}

The royalties are not completely untaxed at the level of the IP-Holding Company. However, as IP Box Regimes either allow exempting a large share of royalty income from taxation or offer reduced tax rates for such income, the tax liability of the IP-Holding Company is very low. 


\subsection{Summarized findings}

The tax planning structures described in the preceding section reveal substantial flaws in the existing national and international tax systems that can be summarized as follows:

(1) A missing enforcement of residence taxation due to

a) no or ineffective CFC rules;

b) in the case of the 'Double Irish Dutch Sandwich' structure a conflicting definition of tax residence in Ireland and the U.S.;

c) tax competition between countries resulting not only in reduced tax rates but also in the establishment of special tax regimes such as IP Boxes in an increasing number of EU member states (and other countries).

(2) A missing enforcement of source taxation due to

a) the non-existence of withholding taxes on royalties both within the EU and with respect to third countries;

b) difficulties in the valuation of IP and relating royalty payments;

c) a lacking taxable presence of multinationals doing business via the internet in customers' residence countries.

\section{How significant is the problem?}

Beyond anecdotic evidence for companies like Google, Microsoft and others, several attempts have been made to clarify how relevant the problem of tax avoidance really is and to find a proxy for the scale of base erosion and profit shifting behavior. Given that true economic profits (i.e. before any avoidance strategy that affects actually reported profits) are not observable, the clear identification of tax avoidance from available data is challenging and existing approaches differ fundamentally. To be very clear at the beginning: there exists evidence that profit shifting takes place. There is, however, no precise and reliable estimate for the amount of tax base erosion due to international profit shifting and aggressive tax planning ${ }^{11}$ respectively.

On the one hand, there are a small number of rather rough estimates which try to derive the volume of profit shifting from aggregate statistics or similar sources. Although these studies receive great attention in public debate, their results have to be treated with caution due to

\footnotetext{
11 We also find it difficult to define aggressive tax planning precisely, see Heckemeyer/Spengel (2013), p. 365. A definition provided by the OECD, that suggests that aggressive tax planning might not accord with the law (OECD (2008), p.87) is misleading since the tax planning strategies described in section 2 are certainly in line with existing law.
} 
serious methodological flaws. We will briefly explain these below. On the other hand, there is a broad strand of studies in the empirical corporate tax literature investigating the phenomenon of corporate tax avoidance with more appropriate methods. These studies employ microeconometric approaches and focus either on the tax sensitivity of reported pre-tax profits at affiliate level or investigate the tax sensitivity of distinct profit shifting strategies. The main evidence provided by this broad empirical literature will be summarized in the second part of this section.

Starting with some stylized numbers from public debates, Richard Murphy (adviser to Tax Justice Network and director of Trades Union Councils) claimed in his report "The Missing Billions" that GBP 12 bn of corporate income tax are lost each year due to tax avoidance by the 700 largest companies in the UK. ${ }^{12}$ With respect to Germany, the German Institute for Economic Research (DIW Berlin) puts forward an estimated revenue loss associated with profit shifting of EUR 90 bn. ${ }^{13}$ For developing countries Oxfam attributes a revenue loss of USD 50 bn to tax avoidance of multinationals. ${ }^{14}$ Although the question of how much revenue is lost due to profit shifting is highly interesting for the public, methodological flaws underlying the estimation of the presented numbers prevent them from being very reliable. Essentially these studies compare taxable profits or actual tax payments with inadequate benchmarks. For instance, taxable income or respectively tax payments in absence of tax avoidance are approximated by using profits from financial accounts multiplied by the statutory tax rate, ${ }^{15}$ company profits from national accounts ${ }^{16}$ or foreign capital stocks multiplied by a deemed return and an average tax rate. ${ }^{17}$ The differences between the actual tax payments or taxable profits and the proxy for benchmark profits/tax payments in absence of tax avoidance can therefore not be clearly attributed to profit shifting activity but rather capture conceptual differences between the compared measures. This makes these figures difficult to interpret.

\footnotetext{
12 Murphy (2008).

13 Bach (2013).

14 Oxfam (2000).

15 This approach of Richard Murphy was discussed by the Oxford University Centre for Business Taxation (2012) in its report "The Tax Gap for Corporation Tax" pointing out that this approach rather captures differences between financial and tax accounting.

16 The DIW compares company profits from national accounts to profits according to the corporate income tax statistics. However, it can be shown that national accounts are themselves affected by profit-shifting activity and any comparison to profits from tax statistics rather picks up conceptual differences but not the volume of profits shifted abroad. For a detailed discussion of the methodological issues related to this approach, please refer to Heckemeyer/Spengel (2008).

17 The shortcomings of this approach are discussed by Fuest and Riedel, who argue that, among other critical assumptions, the role of tax incentives and tax base regulations is neglected in these estimations. See Fuest/Riedel (2010)
} 
Beyond these rough approximations of profit shifting volumes, a wealth of empirical research studies assesses the significance of corporate tax avoidance and its sensitivity with respect to international tax incentives. Turning now to this broad group of empirical approaches, two different strands of literature can be distinguished. The first strand of studies provides rather general evidence for profit shifting by asking how tax rate differentials affect reported pre-tax profits. In their seminal work, Grubert and Mutti as well as Hines and Rice show for the US that there is indeed an empirical relationship between the profitability reported by US multinationals' foreign affiliates and respective host country tax rates. ${ }^{18}$ Huizinga and Laeven provide evidence that reported profits of European subsidiaries depend on their specific tax incentives and profit shifting potential given the structure of the whole multinational group. ${ }^{19}$ Also for Europe, Egger, Eggert and Winner directly compare tax payments of multinational firms and a group of domestic firms which they select by use of propensity score matching to avoid self-selection and find that multinational firms pay substantially less taxes. ${ }^{20}$ Dharmapala and Riedel use a novel identification strategy by asking how a shock in earnings at the parent's level transmits to group entities located in high or low tax countries. ${ }^{21}$ Fuest, Hebous and Riedel study income shifting through debt. They find that financing structures of multinational entities in developing countries react more sensitively to tax differences than in developed countries, suggesting that developing countries with high taxes may be more vulnerable to tax planning. ${ }^{22}$ The findings of these studies strongly support the idea that multinational groups reallocate profits globally as to minimize the overall tax burden. Several other studies corroborate this conclusion although the estimated effect size differs according to the employed dependent profit variable, the measure of the tax incentive and different econometric approaches. A recent quantitative survey of this literature is provided by Heckemeyer and Overesch. ${ }^{23}$

Given the general finding that profits are shifted within a multinational group exploiting the international tax rate differential, the question arises which strategies to reallocate profits within the group can be identified empirically. This is the focus of the second strand of literature. In principle, profits earned in high tax countries can be channeled to lower taxed group entities via debt financing or via non-financial strategies such as transfer pricing and licensing of IP. With respect to debt financing, Desai, Foley and Hines provide empirical evidence that

\footnotetext{
18 Grubert/Mutti (1991); Hines/Rice (1994).

19 Huizinga/Laeven (2008).

20 Egger et al. (2010).

21 Dharmapala/Riedel (2013).

22 Fuest et al. (2011).

23 For recent quantitative survey of this literature see Heckemeyer/Overesch (2013).
} 
multinationals use intra-company loans to mitigate tax payments of subsidiaries in high tax locations. ${ }^{24}$ Clausing shows that intra-firm transfer prices for intra-group transactions are sensitive to international tax rate differentials. ${ }^{25}$ Furthermore, there is robust evidence that tax considerations are important for the intra-company allocation of intangible property. ${ }^{26}$ Desai, Foley and Hines show that large international firms with extensive intra-firm trade and high $\mathrm{R} \& \mathrm{D}$ intensities are the most likely to use tax havens. ${ }^{27}$

Although there are good reasons to believe that transfer pricing and licensing of IP represent the predominant route used to shift profits abroad, ${ }^{28}$ the empirical evidence is not clear cut. Evaluating the general evidence for profit shifting, Heckemeyer and Overesch indeed corroborate the expectation of non-financial profit shifting techniques to play the most important role. Results by Dharmapala and Riedel instead suggest a larger effect of debtfinancing whereas the results of Grubert point to equal shares. ${ }^{29}$

To conclude, empirical evidence on corporate tax avoidance is robust and significant. Moreover, it is clearly shown that transfer-pricing and group financing strategies are used to reallocate profits within the group. It is however less clear which strategy of tax avoidance is most relevant. Finally, very little is known on the actual revenue consequences of these strategies. Empirical studies scarcely extrapolate their estimates to profit shifting volumes. The rather rough approaches discussed in the media are not very reliable and might tend to overestimate the revenue losses.

\section{How would we like international corporate taxation to work?}

How we would like international corporate taxation to work depends on what we expect from the corporate income tax. On the one hand, corporate income taxes can be considered as a substitute for the personal income tax. The income tax is usually levied according to the residence principle. Theoretically, residence-based taxation of corporate income requires direct apportionment of profits to the owners of a company. In practice, this is difficult to achieve. Profits are therefore taxed at the corporate level. Residence based corporate taxation would thus

\footnotetext{
24 Desai et al. (2004).

25 Clausing (2009).

26 Dischinger/Riedel (2011); Karkinsky/Riedel (2012).

27 Desai et al. (2006).

28 The interest rate on intra-group loans can be directly compared to the market interest rate, profit shifting thus being limited to it, whereas there is, in principle, more discretion in setting transfer prices on highly specific group transactions as pointed out by Overesch and Schreiber, see Overesch/Schreiber (2010).

29 Grubert (2003).
} 
imply that multinational companies are liable to tax on their accrued worldwide income. Accordingly, foreign subsidiaries would be treated as transparent for tax purposes.

Alternatively, one could argue, that income tax is considered as an instrument to make firms pay for benefits they get from public services and other advantages provided by the country where they produce or sell their products. According to this concept of source taxation, resident corporations are not liable to tax on their worldwide income but only their domestic profits are subject to tax. Any foreign profits should instead be taxed where they have been generated. ${ }^{30}$

The advantages and disadvantages of these concepts have been discussed extensively in the literature on international taxation. No consensus has so far been reached as to which of these concepts is superior. Against this background, our policy considerations in Section 5 take the existing international income tax systems as a starting point, i.e. corporate taxation is based on income determined by separate accounting and includes elements of both residence and source principle. Given that, the following principles should find widespread support:

1. The international tax system should avoid double taxation of corporate profits.

2. The international tax system should avoid non-taxation of corporate profits.

These rules imply that source and residence based taxes can coexist, provided that taxes on income paid in the source country are credited in the residence country. ${ }^{31}$ Tax avoidance typically implies that these rules are violated. In addition, tax avoidance may distort the capital allocation because it distorts competition between firms with different opportunities to avoid taxes.

\section{Policies to address profit shifting and tax avoidance}

For tackling profit shifting and tax avoidance it is useful to distinguish four starting points, as explained in the introduction:

(1) Extension of residence taxation;

(2) Extension of source taxation;

(3) Fundamental reforms of corporate income taxation;

(4) Stricter reporting and transparency requirements.

\footnotetext{
30 Clearly, if source country taxes are credited against residence based taxes, both types of taxes can coexist without creating double taxation.

31 Clearly, the notion that corporate income should be taxed once, rather than twice or not at all, raises the question whether taxation at a very low rate or even zero rating is acceptable.
} 
In this section we present specific policy options for each approach and analyze their potential to tackle profit shifting in general and IP-based tax planning structures as presented in section 2 in particular.

\section{(1) Extension of residence taxation}

To avoid profit shifting by strengthening residence taxation one option is to tighten CFC rules so that they effectively prevent sheltering passive low-taxed royalty or interest income from residence taxation. The European Commission and the OECD consider this option. With respect to the 'Double Irish Dutch Sandwich' arrangement described in Section 2 another policy option is to harmonize the criteria that determine tax residence across countries to avoid qualification conflicts and resulting double non-taxation.

Both measures for strengthening residence taxation have the potential to reduce tax avoidance of multinationals. However, not all countries might be willing to implement them because while some countries lose as a result of profit shifting other countries gain. It is for example not in the interest of the U.S. to tighten CFC rules or the rules for tax residence because U.S. multinational firms would then lose the competitive advantage of avoiding European corporate income taxes on foreign income. Also various other European countries, among them Luxembourg, the Netherlands, Switzerland and the UK, compete for tax bases and jobs by drastically reducing residence taxation on mobile income through IP Box Regimes. Hence, waiting for these countries to tighten residence taxation is not a realistic option. However, pressure could be put on countries by establishing a set of rules which prevents them from operating specific tax incentives like IP Box Regimes. One possibility for this is the existing EU code of conduct for business taxation. ${ }^{32}$ So far, the code of conduct has been successful since many member states have withdrawn tax regimes considered as harmful in the past 15 years. However, the code of conduct is legally not binding and does not offer precise definitions of harmful tax regimes. It is therefore not clear whether the code of conduct covers IP Box Regimes. Another possibility is the application of state aid provisions by the European Commission to IP Box Regimes and its approval by the European Court of justice. One has to be aware, however, that even if IP Box Regimes were ruled out profit shifting and aggressive tax planning would remain.

\footnotetext{
32 European Communities (1998).
} 


\section{(2) Extension of source taxation}

One possibility to strengthen source taxation is the implementation of deduction restriction rules for payments on intra-group contractual relations such as interest and royalty payments. Many countries already apply so-called thin-capitalization rules or earnings-stripping rules to counter profit shifting via intra-group or even third-party debt-financing. To tackle profit shifting via licensing, comparable deduction restriction rules for intra-group royalty payments could be introduced. Both options are included as action no. 4 in the OECD's action plan adopted by the G-20 in July 2013. However, the implementation of such rules has serious drawbacks. They do not only affect arrangements designed to avoid taxes but also arrangements which exist for good economic reasons. Moreover, deduction restriction rules reduce the consistency of the law and, in particular, often cause double taxation. This is because the underlying payments although not deductible in the source country are still considered as taxable income in the residence country. There is sufficient theoretical and empirical evidence that the extension of source taxation, which results in a definite tax burden at source, has a negative impact on the level of investment.

Another policy option for strengthening source taxation is the implementation of a general antiavoidance rule (so-called GAAR) into the tax code as proposed by the European Commission in December 2012. ${ }^{33}$ GAAR would disallow the deductibility of payments such as royalties and interest to tax havens under certain conditions. This policy option is also not recommendable due to several reasons. First, it is difficult to draw the line between a wholly artificial structure and one that has economic substance. Hence, it might be quite easy for companies to circumvent the application of GAAR. Second, it has to be emphasized that tax planning, even if considered as aggressive, is not illegal. Third, the effectiveness of such a rule depends strongly on the interpretation by the national courts, which leads to considerable uncertainty in the application of tax law.

A third possibility of enhancing source taxation to particularly avoid profit shifting by licensing is to ensure an adequate valuation of intangible assets and relating royalty payments. With respect to the transfer of intangibles this can be done by implementing an adjustment clause in the national tax code which provides tax authorities with the opportunity to levy additional exit taxes if the earnings potential turns out to be substantially higher than initially expected. ${ }^{34}$ Applying such a rule also to buy-in payments made under cost-sharing agreements would

33 European Commission (2012b).

34 In 2008 such an adjustment clause was introduced into the German tax code in $\S 1$ Abs. 3 AStG. 
drastically reduce the tax advantage stemming from IP tax planning strategies. Concerning the deductibility of royalty payments, countries need to strictly apply the arm's length principle to avoid base erosion. However, as assessing arm's length prices for intra-group royalties is very difficult, the enforcement of the arm's length standard does not ensure an objective valuation of transfer prices. Focusing on profit-based methods, like, for example, the profit split method to determine transfer prices might improve the arm's length principle by making transfer prices more objective. As already mentioned with respect to measures for strengthening residence taxation, here again the problem occurs that it might not be in the interest of all countries to strengthen source taxation. Ireland, for example, has few incentives to adapt its transfer pricing rules if companies using the existing rules create jobs for highly qualified employees in Ireland.

A promising way of tackling profit shifting could be the extension of source taxation by imposing withholding taxes on interest and royalty payments which then would be creditable in the residence country. Hence, double taxation would be avoided. Raising withholding taxes on both royalties paid to EU member states and royalties paid to third countries would also render the IP-based tax planning strategies described in Section 2 ineffective. Such a reform towards more source taxation at the international level requires a modification of bilateral tax treaties and the EU Interest and Royalty Directive. Moreover, pressure has to be put on European countries that do not levy withholding tax on interest (e.g. Germany) or royalties (e.g. the Netherlands) respectively according to their national tax law. It thereby has to be stressed, that enhancing source taxation also requires that residence countries credit withholding taxes. It is surprising for us that neither the European Commission nor the OECD considers this option. In our view the levy of withholding taxes by source countries and the obligation of resident countries to credit them is - given the ongoing public debate - an appropriate measure to ensure that multinationals pay a fair share of taxes in countries where they operate.

Withholding taxes are less helpful when it comes to companies that do not create a taxable presence in countries where they carry out functions and sell their products. This is especially true for multinationals selling their goods via the internet. If, for example, Ireland or the Netherlands levied a withholding tax on royalties, this would render the 'Double Irish Dutch Sandwich' structure void, but multinationals with online sales could still keep their effective tax rates low by locating their operating company in a low tax country like Ireland and thereby avoiding a nexus in all other countries. Another option to enhance source taxation is therefore to ensure the creation of a taxable presence in the source country. This can be done by revising the transfer pricing rules for group service providers and, especially, by adapting the concept 
of permanent establishments to the digital economy. One possibility for the latter is to stipulate the creation of a PE in the customer's residence state upon collection of customer data. ${ }^{35} \mathrm{An}$ additional option would be an effective collection of VAT in the digital economy as considered by the OECD (see action no. 1).

Due to the revenue redistribution that comes along with coordinated reforms to strengthen source taxation, such measures might also face difficulties to find broad international approval. Apparently, this is because if source taxation is increased, residence countries will at the same time lose tax revenue due to a higher amount of creditable foreign taxes or exempt foreign income. Until countries or regions have no clear indication about how much they will gain and lose in tax revenue due to the extension of source taxation on capital imports and the reduction of residence taxation of capital exports it is therefore not clear whether measures to prevent aggressive tax planning are really desirable. Here, further research on the revenue implications is necessary.

\section{(3) Fundamental reforms of corporate income taxation}

Profit shifting can also be addressed by fundamental reforms of the international tax system. Currently, the separate entity principle based on transfer prices following the arm's length standard prevails. As described above, the enforcement of the arm's length standard often fails due to the high specificity of intra-firm goods. Therefore, the European Commission proposed to replace the system of separate accounting by formula apportionment. ${ }^{36}$ According to the Common Consolidated Corporate Tax Base (CCCTB), the income of a group is consolidated and split between tax authorities according to a formula that includes proportional assets, payroll and sales. This concept makes transfer prices obsolete and avoids the related measurement problems. However, defining the elements of the formula as well as their respective weights is a controversial issue and the determination of transfer prices remains necessary for transactions at the boundaries of the EU. Although formula apportionment will mitigate important shortcomings of separate accounting it will, at the same time, create new distortions. ${ }^{37}$ Beyond concerns against a formula apportionment from a theoretical point of view it has to be stressed, however, that in particular the sales factor in such a formula could turn out to be very robust against profit shifting since the consumer market of multinationals cannot be manipulated.

\footnotetext{
35 Collin/Colin (2013), pp. 121f.

36 European Commission (2011).

37 Devereux (2004).
} 
An alternative approach would be to introduce a destination-based cash flow tax which ties taxation of corporations to the location of consumption. ${ }^{38}$ Again, as for a CCCTB, the appeal of this concept is that consumption is likely to be less mobile and more difficult to manipulate for tax purposes than income.

Both fundamental reform options are promising and may solve central problems of the current tax system. However, the optimal design of such rules has to be elaborated further and there is currently no consensus between countries in sight about either of these reform options. Hence, the more fundamental approaches are not an appropriate measure to tackle profit shifting in the short run. Rather, they would require a huge reform effort and need a considerable degree of international coordination and harmonization. It could even turn out that either a CCCTB or a destination-based cash flow tax has to be implemented on a world-wide basis. It is therefore not surprising that fundamental reforms of income taxation are not on the agenda of either the European Commission or the OECD.

\section{(4) Stricter reporting and transparency requirements}

As a fourth approach to tackle profit shifting and tax avoidance we should mention an entirely different policy option: a change in reporting and publicity rules regarding taxes paid by multinational companies. One proposal in this respect, the so-called country-by-country reporting, was initially brought forward by civil society organizations ${ }^{39}$ and is now also discussed in certain countries (e.g. Germany) ${ }^{40}$ and at the level of the EU. ${ }^{41}$ Such a measure would require multinationals to publicly disclose data on the financial performance like sales, purchases, labour costs and number of employees, financing costs, pre-tax profits, nature and value of assets and the tax charge split between current and deferred tax to the public on a country-by-country basis. In this context it is important to distinguish between reporting to the tax authorities and public disclosure of tax information. The main objective of country-bycountry reporting proposals is to achieve public disclosure.

Proponents of this approach essentially pursue two objectives. Firstly, companies may be held accountable for the amount of tax they pay or fail to pay in individual countries. Secondly, governments and their tax administrations may be held accountable for the way in which they

\footnotetext{
38 Bond/Devereux (2002); Auerbach et al. (2010).

39 The idea was first developed by Richard Murphy, a former chartered accountant working for Tax Justice Network and other civil society organizations.

40 See Fraktionen SPD und BÜNDNIS 90/DIE GRÜNEN (2013), suggesting a country-by-country reporting for multinational investors in Germany.

41 Brunsden (2013).
} 
treat multinational investors. Whether public debate about taxes paid by multinationals in different countries can act as a substitute for legislation or whether it creates pressure for governments to improve tax legislation is an open question. Additional open issues are related to the objective and justification, legal aspects and the mechanism for disclosure of country-bycountry reporting. ${ }^{42}$

Objective and justification: Country-by-country reporting was initially mainly discussed to increase transparency in the extractive industries (e.g. oil, gas and mining industries) for developing countries. Revenues from natural resources are an important source of income for these countries. The view here is that governments in developing countries find it extremely difficult to collect taxes that are properly due from a small number of companies. Transparency in this respect might be useful in combating corruption. Whether combating corruption justifies the extension of country-by-country reporting to other industry-sectors is a controversial issue. Profit shifting and tax planning - even if considered as aggressive - is not per se against the law. It has been elaborated in section 3 of this paper in detail that profit shifting takes place, although the scale of such activity is not clear at all. Moreover, there are certainly many other taxpayers than multinationals (in particular individuals) conducting tax planning and income shifting. If there are unintended gaps or loopholes in the tax laws, then, above all, the legislator has to remove them. As pointed out in section 2 and discussed above, these gaps and loopholes as well as the measures for closing them are well known.

Legal aspects: Country-by-country reporting has to consider legal restrictions. Here, first of all, the confidentiality of tax returns in most countries around the globe has to be mentioned. Moreover, the competitive position of multinationals could be jeopardized if country-bycountry reporting is not a universal standard. In addition, it could be possible that such information is misused and, hence, increases the reputational risk of multinationals.

Mechanism for disclosure: Advocates of country-by-country reporting propose as an instrument for disclosure the consolidated financial accounts of multinationals, possibly by an extension of the segmental reporting requirements laid down in the International Financial Reporting Standards (IFRS). Again, here, several concerns arise. First, it is doubtful that consolidated financial accounts are the proper instrument for country-by-country reporting since these accounts provide decision useful information about the group of companies as a whole single entity. Second, like other accounting standards such as US-GAAP, IFRS follow a forward

42 For a detailed discussion of county-by-country reporting see Oxford University Centre for Business Taxation (2011) 
looking approach, while country-by-country tax reporting is strictly backward looking. This is relevant for example if deferred taxes are required to be reported. This part of the total tax charge is based on reliable expectations about the future. Third, accounting standards already prescribe considerable reporting requirements such as segmental reporting and the tax reconciliation. This is done by a regional or product-based reporting. There is, however, no obligation to report about the tax charge in such a detail as proposed by country-by-country reporting. This aspect relates to the legal restrictions mentioned above. Therefore, a special disclosure form independent from financial accounts seems to be more adequate. Again, legal concerns remain if this information was made available to the public.

To summarize, the objectives and the justification of stricter reporting and transparency requirements for multinationals are vague. Moreover, depending on how the reporting requirements are implemented, there may be a trade-off between the administrative effort and cost of country-by-country reporting and the potential benefit in terms of improved tax compliance. A potentially more efficient way to crowd back tax avoidance by collecting more information on tax planning strategies would be to implement a 'disclosure of tax avoidance schemes-regime' as it already exists in the $\mathrm{UK}^{43}$ and some other countries and which requires tax advisers to disclose the tax planning structures they sell to their customers.

\section{Concluding remarks}

This paper contributes to the recent debate on tackling profit shifting and tax avoidance and aggressive tax planning strategies by multinational firms.

Profit shifting and tax planning - even if considered as aggressive - are not violations of the law, even if they are in conflict with what was intended. As described for prominent IP-based profit shifting models, multinational investors benefit from unintended gaps or loopholes in the tax laws. These gaps and loopholes are well known. It is up to tax legislators to remove them. There is solid empirical evidence demonstrating that profit shifting does indeed take place. The scale of profit shifting and the impact on tax revenue are difficult to measure, but it is plausible that the tax revenue losses are significant, as are the distortions in competition between firms which, due to their particular characteristics, differ in the opportunities to avoid taxes.

43 The regime was introduced in 2004, for details see HM Revenue \& Customs (2013). 
As a guideline for policies against tax avoidance by multinational firms, we suggest that the international tax system should at the same time avoid double taxation and non-taxation of corporate profits.

Measures directed against profit shifting which are currently discussed, including the measures suggested by the European Commission and the OECD, can be summarized under the following four headings:

(1) Extension of residence taxation;

(2) Extension of source taxation;

(3) Fundamental reforms of corporate income taxation;

(4) Stricter reporting and transparency requirements.

Our findings suggest that the enforcement of residence taxation is a difficult task, mainly because some countries are likely to be reluctant to move into this direction and unilateral action can only address certain forms of income shifting.

The extension of source taxation seems to be more promising. Here, anti-avoidance measures, like deduction restriction rules for interest and royalty payments or a general anti-avoidance rule (GAAR), are not recommended as the first may cause double taxation and the second is likely to be ineffective.

In the short run, we especially recommend to impose new or to extend existing withholding taxes on interest and royalty payments. This measure effectively tackles currently used tax planning structures and does not distort investment decisions as long as withholding taxes are credited in the residence country. Surprisingly, such a proposal is neither on the current agenda of the European Commission nor of the OECD. Since the redistribution of tax revenues between countries will be affected by imposing withholding taxes, it is, however, not clear whether this measure is desirable and whether countries are really willing to crowd back tax avoidance. Here, further research on the revenue implications is necessary.

For the longer perspective, we recommend to investigate the more fundamental approaches such as the destination-based cash flow tax or the СССТВ with regard to changes of the international system of income taxation, the allocation of taxing rights as well as the enforcement of the tax and the resulting revenue implications in greater detail.

Whether stricter reporting and transparency requirements for multinational companies are a promising way forward is not clear. The objectives are still vague. Moreover, in particular a 
country-by-country reporting faces considerable legal constraints and a mechanism for disclosure has to be elaborated before decisions can be made regarding the likely impact of this proposal on the taxation of multinational firms. 


\section{References}

Auerbach, A./Devereux M./Simpson, H. (2010), Taxing corporate income, in: Mirrlees, J./Adam, S./Besley,T./Blundell, R./Bond, S./Chote, R./Gammie, M./Johnson, P./Myles, G./Poterba, J. (Eds.), Dimensions of Tax Design: The Mirrlees Review, Oxford University Press, pp. 837-893.

Bach, S. (2013), Unternehmensbesteuerung: Hohe Gewinne - mäßige Steuereinnahmen, DIW Wochenbericht, pp. 3-13.

Bond, S.R./Devereux, M.P. (2002), Cash Flow Taxes in an Open Economy, CEPR Discussion Paper No. 3401.

Brunsden J. (2013), EU Seeks Country-by-Country Tax Disclosure for Large Companies, http ://www.bloomberg.com/news/2013-05-23/eu-seeks-country-by-country-tax-disclosure -for-large-companies.html.

Clausing, K.A. (2009), Multinational Firm Tax Avoidance and Tax Policy, National Tax Journal, pp. 703-725.

Collin, O./Colin, N. (2013), Task Force on Taxation of the Digital Economy, Report commissioned by the French Government, http://www.hldataprotection.com/files/2013 /06/Taxation_Digital_Economy.pdf.

Desai, M.A./Foley, C.F./Hines, J.R. (2004), A Multinational Perspective on Capital Structure Choice and Internal Capital Markets, Journal of Finance, pp. 2451-2487.

Desai, M.A./Foley, C.F./Hines, J.R. (2006), The Demand for Tax Haven Operations, Journal of Public Economics, pp. 513-531.

Devereux, M.P. (2004), Debating Proposed Reforms of the Taxation of Corporate Income in the European Union, International Tax and Public Finance, pp. 71-89.

Dharmapala, D./Riedel, N. (2013), Earnings Shocks and Tax-Motivated Income Shifting: Evidence from European Multinationals, Journal of Public Economics, pp. 95-107.

Dischinger, M./Riedel, N. (2011), Corporate Taxes and the Location of Intangible Assets within Multinational Firms, Journal of Public Economics, pp. 691-707.

Egger, P./Eggert, W./Winner, H. (2010), Saving Taxes Through Foreign Plant Ownership, Journal of International Economics, pp. 99-108. 
European Commission (2011), Proposal for a Council Directive on a Common Consolidated Corporate Tax Base (CCCTB), Brussels COM(2011) 121/4, http://ec.europa.eu/taxatio n_customs/resources/documents/taxation/company_tax/common_tax_base/com_2011 _121_en.pdf.

European Commission (2012a), Communication from the Commission to the European Parlia ment and the Council - An Action Plan to strengthen the fight against tax fraud and tax evasion, Brussels COM(2012) 722, http://ec.europa.eu/taxation_customs/resources /documents/taxation/tax_fraud_evasion/com_2012_722_en.pdf.

European Commission (2012b), Commission Recommendation of 6.12 .2012 on aggressive tax planning, Brussels, C(2012) 8806, http://ec.europa.eu/taxation_customs/resources/doc uments/taxation/tax_fraud_evasion/c_2012_8806_en.pdf.

European Commission (2012c), Commission Recommendation of 6.12 .2012 regarding measures intended to encourage third countries to apply minimum standards of good governance in tax matters, Brussels C(2012) 8805, http://ec.europa.eu/taxation_custo $\mathrm{ms} /$ resources/documents/taxation/tax_fraud_evasion/c_2012_8805_en.pdf.

European Communities (1998), Conclusions of the ECOFIN Council meeting on 1 December 1997 concerning taxation policy, Official Journal of the European Communities 98/C 2/01, pp. 1-6.

European Council (2013), 22 May 2013 Conclusions, Brussels EUCO 75/1/13, http://www.co nsilium.europa.eu/uedocs/cms_Data/docs/pressdata/en/ec/137197.pdf.

Fraktionen SPD und BÜNDNIS 90/DIE GRÜNEN (2013), BT-Drs. 17/13717, http://dip21.bu ndestag.de/dip21/btd/17/137/1713717.pdf.

Fuest, C./Riedel, N. (2010), Tax Evasion and Tax Avoidance in Developing Countries: The Role of International Profit Shifting, Oxford University Centre for Business Taxation, Working Paper 10/12.

Fuest, C./Hebous, S./Riedel, N. (2011), International debt shifting and multinational firms in developing economies, Economics Letters, pp. 135-138.

Grubert, H. (2003), Intangible Income, Intercompany Transactions, Income Shifting and the Choice of Location, National Tax Journal, pp. 221-242.

Grubert, H./Mutti, J. (1991), Taxes, Tariffs and Transfer Pricing in Multinational Corporate Decision Making, Review of Economics and Statistics, pp. 285-293. 
Heckemeyer, J.H./Overesch, M. (2013), Multinationals' profit response to tax differentials: Effect size and shifting channels, Working Paper, University of Cologne.

Heckemeyer, J.H./Spengel, C. (2008), Ausmaß der Gewinnverlagerung multinationaler Unternehmen, empirische Evidenz und Implikationen für die deutsche Steuerpolitik, Perspektiven der Wirtschaftspolitik, pp. 37-61.

Heckemeyer, J.H./Spengel, C. (2013), Maßnahmen gegen Steuervermeidung: Steuerhinterziehung versus aggressive Steuerplanung, Wirtschaftsdienst, pp. 363-366.

Hines, J.R./Rice, E.M. (1994), Fiscal Paradise: Foreign Tax Havens and American Business, Quarterly Journal of Economics, pp. 149-182.

HM Revenue \& Customs (2013), Disclosure of tax avoidance schemes, http://www.hmrc.gov. uk/aiu/summary-disclosure-rules.htm.

Huizinga, H./Laeven, L. (2008), International Profit Shifting within Multinationals: A MultiCountry Perspective, Journal of Public Economics, pp. 1164-1182.

Karkinsky, T./Riedel, N. (2012), Corporate Taxation and the Choice of Patent Location within Multinational Firms, Journal of International Economics, pp. 176-185.

Murphy, R. (2008), The Missing Billions - the UK Tax Gap, TUC, http://www.tuc.org.uk/touc hstone/Missingbillions/1missingbillions.pdf.

OECD (2008), Study into the Role of Tax Intermediaries, ISBN-978-92-64-04179-0, http://w ww.oecd.org/dataoecd/28/34/39882938.pdf.

OECD (2013a), Addressing Base Erosion and Profit Shifting, http://www.keepeek.com/Digita 1-Asset-Management/oecd/taxation/addressing-base-erosion-and-profit-shifting_97892 64192744-en.

OECD (2013b), Action Plan on Base Erosion and Profit Shifting, http://www.keepeek.com/Di gital-Asset-Management/oecd/taxation/action-plan-on-base-erosion-and-profit-shifting _9789264202719-en.

Overesch, M./Schreiber, U. (2010), Asset Specificity, International Profit Shifting, and Investment Decisions, Zeitschrift für Betriebswirtschaft, pp. 23-47.

Oxfam (2000), Tax Havens: Releasing the Hidden Billions for Poverty Eradication, Oxfam International Policy Paper, ISBN 9781848146419. 
Oxford University Centre for Business Taxation (2011), Transparency in reporting financial data by multinational corporations, Report of a group chaired by Michael Devereux, Oxford, http://www.sbs.ox.ac.uk/centres/tax/Documents/reports/Transparency_reporti ng_multinationals_july2011.pdf.

Oxford University Centre for Business Taxation (2012), The Tax Gap for Corporation Tax, R eport commissioned by the National Audit Office (NAO), Paper 3, http://www.sbs.ox. ac.uk/centres/tax/Documents/reports/TaxGap_3_12_12.pdf.

Pinkernell, R. (2012), Ein Musterfall zur internationalen Steuerminimierung durch USKonzerne, Steuer und Wirtschaft, pp. 369-374.

Sandell, J. (2012), The Double Irish and the Dutch Sandwich: How Some U.S. Companies Are Flummoxing the Tax Code, Tax Notes International, pp. 867-878.

Sullivan, M.A. (2012), Economic Analysis: Should Tech and Drug Firms Pay More Tax?, Tax Notes International, pp. 655-656. 